\title{
What is the contribution of occupational environmental factors to the occurrence of scleroderma in men?
}

\author{
Alan J Silman, Steven Jones
}

\begin{abstract}
An occupational analysis of 56 men with scleroderma in the United Kingdom showed no evidence that silica exposure was implicated in the onset of the disease, in contrast with older published reports suggesting that such exposure explained an important proportion of the occurrence of the disease in men. Of the major occupational exposures suggested from case reports, only organic solvents were reported to any extent in this series. No significant increase in exposure to organic solvents was noted, however, in a case control analysis.
\end{abstract}

(Ann Rheum Dis 1992; 51: 1322-1324)

Scleroderma is a rare disease which is more common in women than men in all groups studied. ${ }^{1-3}$ The excess is greatest in women who have not reached the menopause, suggesting that hormonal or reproductive factors, or both, may affect the aetiology of this disease. ${ }^{4}$ Despite these observations there is considerable evidence that environmental factors may explain the occurrence of scleroderma in individual patients. Exposure to silica dust in miners, stone masons, and others, ${ }^{5-11}$ exposure to aromatic ${ }^{12-14}$ and aliphatic $^{15-18}$ organic solvents, and exposure to vinyl chloride, ${ }^{19}$ epoxy resins, ${ }^{20}$ and formaldehyde $^{21}$ have all been linked to the occurrence of scleroderma. Thus an attractive hypothesis is that, from an aetiological point of view, there are two forms of scleroderma: a predominantly female variant related to hormonal or reproductive factors and a predominantly male variant related to occupational exposure. There have, however, been few studies quantifying the contribution of occupational factors to the occurrence of scleroderma in men. This, in part, reflects the rarity of the disease in this group. In Pittsburgh, a mining area, $43 \%$ of 60 male patients seen in a ten year period worked in occupations exposed to silica, twice the rate of local hospital controls. ${ }^{7}$ An uncontrolled study of a similar group from (the former East) Germany suggested that $77 \%$ of male patients had been exposed to silica. ${ }^{10}$

We have conducted a survey of male patients with scleroderma attending hospital in the United Kingdom to investigate the influence of exposure to silica and other occupational agents on the occurrence of scleroderma in men

Subjects and methods

DESIGN

The study had two phases. The first was a cross sectional survey of men with scleroderma to determine their possible occupational exposure. The second was an analytical study using a case control design to compare any possible exposures determined from the case studies with a suitable comparison group. Such a retrospective case control approach is the only practical way to investigate the influence of a number of exposures in a rare disease. It has the limitation, however, that if the individual exposures themselves are rare, then it may be difficult to recruit sufficient subjects for a study with adequate statistical power.

SUBJECTS

Subjects were recruited from registers of patients with scleroderma from centres within the United Kingdom with a major interest in scleroderma and connective tissue disease. The entry criterion was based on the consultant's diagnosis of scleroderma with typical skin changes, and the date of diagnosis was used to determine premorbid exposure. Sixty five men with scleroderma were notified of whom four had died, two were still in full time education, and three refused to participate, leaving 56 patients available for the survey. For the second phase the controls were drawn from two sources. As the subjects were derived from a nationwide series it was important to match for area of residence to avoid the possibility of area or occupation confounding. These two sources were: $(a)$ the patients were asked to provide three male friends within five years of age and (b) the general practitioner of each patient was approached to provide the names of three male patients within five years of the age of the patient. There was considerable difficulty in recruiting subjects for the two comparison groups and, because of the methodological interest, these difficulties have been summarised elsewhere. $^{22}$ In total there were 56 general practitioner controls and 41 friend controls who provided data.

\section{SURVEY METHOD}

Occupational exposure was determined by a postal questionnaire. A second questionnaire was sent if a reply had not been received within four weeks. Occupational exposure was determined in two ways. First the subjects were asked to give detailed histories of their occupations since leaving school up to the date of diagnosis. Information was sought on the name and location of any factory or place of work together with a detailed job title. These job 
histories were assessed, blind to the case or control status, by an experienced occupational hygienist using standard occupational directories. Based on the latter each occupational period was scored for either nil, possible, or probable exposure to four types of agents: silica dusts, epoxy resins, formaldehyde, and organic solvents. This approach could not be used to evaluate exposure to vinyl chloride. Secondly the subjects themselves were asked to recall exposure to this list of agents by the question: 'Have you ever worked extensively with any of the following'. Some occupational exposures with no known scleroderma association were also included, such as wool, leather, and printing.

\section{ANALYSIS}

A dummy date of diagnosis was allocated for the controls based on the date of diagnosis in their matched patient.

The exposure period of interest was taken as the interval between leaving school and diagnosis in the patients and the 'dummy' date of diagnosis in the controls. Matching, however, was not maintained in the analysis as this would have required excluding patients for whom a matched control was not available, particularly for the friend controls. Odds ratios and 95\% confidence intervals were calculated separately for the comparisons with general practitioner and friend controls although, in many instances, exposure rates were so rare that exact confidence limits were difficult to estimate. In the one exposure with sufficient data (organic solvents) we looked for an effect of duration based on the cumulative occupational exposure. The $\chi^{2}$ test for trend was used to determine any trend towards increasing risk.

Table 1 Demographic characteristics of subjects

\begin{tabular}{llll}
\hline & $\begin{array}{l}\text { Patients } \\
(n=56)\end{array}$ & $\begin{array}{l}\text { General practice } \\
\text { controls }(n=56)\end{array}$ & $\begin{array}{l}\text { Friend controls } \\
(n=41)\end{array}$ \\
\hline Mean (SE) age (years) & $57 \cdot 3(2 \cdot 0)$ & $\begin{array}{l}57 \cdot 9(2 \cdot 2) \\
28 \cdot 1(2 \cdot 1)\end{array}$ & $\begin{array}{l}59 \cdot 5(2 \cdot 7) \\
25 \cdot 1(2 \cdot 1)\end{array}$ \\
\hline Mean (SE) years in employment & $28 \cdot 4(1 \cdot 9)$ & 28.10 \\
\hline
\end{tabular}

\section{Results}

The 56 patients had a mean age of 57 years and a mean length of occupational exposure before diagnosis of 28 years. These results were similar to the two comparison groups considered separately (table 1). No definite exposure to silica was found for any of the patients either from their own reports or from the occupational analysis (table 2). Two patients were classified as having possible silica exposure. Similarly exposure to epoxy resins, formaldehyde, or vinyl chloride was only rarely reported. In contrast, organic solvent exposure was reported in over $30 \%$ of patients. The occupational analysis suggested that $11 \%$ had probable and a further $34 \%$ possible exposure to these agents.

The patient/control analysis (table 2) suggested there was an increase in self reporting of exposure to organic solvents among the patients. The increased risk based on occupational analysis of job titles was smaller. Confidence intervals were wide, however, limiting interpretation. Further analysis of exposure to organic solvents was undertaken based on the duration of exposure considered as four strata: nil, $0-9,10-19$, and $\geqslant 20$ years. There was no trend of increasing odds ratio compared with either the general practitioner $\left(\chi^{2}\right.$ trend 0.34$)$ or the friend $\left(\chi^{2}\right.$ trend 0.51$)$ controls with most of the odds ratios centred around unity.

\section{Discussion}

Most of the male patients reported here had not experienced occupational exposure to agents previously reported to be related to scleroderma. There was no evidence that exposure to silica dust was a predominant exposure as reported in other series. ${ }^{7} 10$ Exposure to organic solvents was reported by a substantial proportion of patients but the results of the case control analysis do not confirm any increase in risk, though the confidence intervals were wide. Given the numbers available and the total exposure rate to organic solvents based on the job descriptions, the minimum detectable increase $(\alpha=0.05)$ in the odds ratio with a power of $80 \%$ was $2 \cdot 8$.

Table 2 Exposure of patients before disease onset to specific agents and results of case control analysis

\begin{tabular}{|c|c|c|c|c|c|}
\hline \multirow[t]{3}{*}{ Exposure } & \multirow{3}{*}{$\begin{array}{l}\text { Number (\%) } \\
\text { of cases } \\
\text { exposed }\end{array}$} & \multicolumn{4}{|c|}{ Comparison with } \\
\hline & & \multicolumn{2}{|c|}{ General practitioner control } & \multicolumn{2}{|c|}{ Friend control } \\
\hline & & Odds ratio & $(95 \% C I)$ & Odds ratio & $(95 \% C I)$ \\
\hline $\begin{array}{l}\text { Self report } \\
\text { Vinyl chloride } \\
\text { Polyvinyl chloride } \\
\text { Silica } \\
\text { Organic solvents }\end{array}$ & $\begin{aligned} 1 & (1 \cdot 7) \\
2 & (3 \cdot 6) \\
0 & (0) \\
18 & (32 \cdot 1)\end{aligned}$ & $\begin{array}{l}1.0 \\
2.0 \\
\text { NA } \\
1.7\end{array}$ & $\begin{array}{l}(0 \cdot 06 \text { to } 16 \cdot 4) \\
(0 \cdot 18 \text { to } 23 \cdot 1) \\
(0 \cdot 7 \text { to } 4 \cdot 1)\end{array}$ & $\begin{array}{l}0.7 \\
1.5 \\
\text { NA } \\
2.3\end{array}$ & $\begin{array}{l}(0.04 \text { to } 12.0) \\
(0.13 \text { to } 16.9) \\
(0.9 \text { to } 6.2)\end{array}$ \\
\hline \multicolumn{6}{|l|}{ Job description } \\
\hline $\begin{array}{l}\text { Probable+possible } \\
\text { Epoxy resins }\end{array}$ & $2(3 \cdot 6)$ & 1.0 & $(0 \cdot 13$ to $7 \cdot 2)$ & $1 \cdot 4$ & $(0 \cdot 12$ to $16 \cdot 1)$ \\
\hline $\begin{array}{l}\text { Probable } \\
\text { Probable+ possible } \\
\text { Formaldehyde }\end{array}$ & $\begin{array}{l}0(0) \\
3(5 \cdot 4)\end{array}$ & $\begin{array}{l}\text { NA } \\
1.7\end{array}$ & $(0 \cdot 4$ to $7 \cdot 3)$ & $\begin{array}{l}\text { NA } \\
0.5\end{array}$ & $(0.15$ to 1.9$)$ \\
\hline $\begin{array}{l}\text { Probable } \\
\text { Probable+possible } \\
\text { Organic solvents }\end{array}$ & $\begin{array}{l}0(0) \\
4(7 \cdot 1)\end{array}$ & $\begin{array}{l}\mathrm{NA} \\
0.8\end{array}$ & $(0 \cdot 2$ to $3 \cdot 0)$ & $\begin{array}{l}\text { NA } \\
0.9\end{array}$ & $(0 \cdot 2$ to $4 \cdot 4)$ \\
\hline $\begin{array}{l}\text { Probable } \\
\text { Probable + possible }\end{array}$ & $\begin{array}{r}6(10 \cdot 7) \\
25(44 \cdot 6)\end{array}$ & $\begin{array}{l}1.5 \\
1.3\end{array}$ & $\begin{array}{l}(0 \cdot 4 \text { to } 5 \cdot 6) \\
(0.6 \text { to } 2 \cdot 7)\end{array}$ & $\begin{array}{l}1 \cdot 1 \\
1 \cdot 0\end{array}$ & $\begin{array}{l}(0 \cdot 3 \text { to } 4 \cdot 0) \\
(0.5 \text { to } 2 \cdot 4)\end{array}$ \\
\hline
\end{tabular}

${ }^{*} \mathrm{NA}=$ not applicable; $\mathrm{CI}=$ confidence interval. 
There are a number of methodological issues to be addressed in interpreting these data. Firstly scleroderma is exceptionally rare and, despite approaching all the major scleroderma units in the United Kingdom, only a small number of patients could be obtained-far fewer than are needed to estimate the risk of each exposure separately. The main question addressed by this work, however, was how many of current male patients in the United Kingdom have been exposed to a suspected occupational aetiological agent. Organic solvents apart, the answer is almost none.

The difficulty in obtaining controls is of concern and the failure to obtain three controls for each patient reduced the power of the comparison. Given that the major difficulty was in obtaining controls it is difficult to see how this will have introduced bias. The advantage of the occupational analysis was that it was undertaken blind, ruling out observer bias in exposure allocation. It is possible that the patients and controls could have had poor recall for the nonsolvent exposures listed but not identified by the occupational analysis, such as vinyl chloride, but this seems unlikely.

In conclusion, known occupational exposures suggested from isolated case reports do not explain most of the cases of scleroderma in men in the United Kingdom.

We acknowledge with gratitude the cooperation of Dr Caro Black, Professor Peter Maddison, Professor Malcolm Jayson, Professor Paul Bacon, and Dr Asad Zoma for allowing the authors to contact their patients. We are also grateful to $\mathrm{Mr}$ Brian Pannet, occupational hygienist, and Dr David Coggon of the Medical Research Council environmental epidemiology unit fo the occupational exposure analysis.

1 Medsger T A, Masi A T. Epidemiology of systemic sclerosis (scleroderma). Ann Intern Med 1971; 74: 714-21.

2 Michet C J, McKenna C H, Elveback L R, Kaslow R A Kurland L T. Epidemiology of systemic lupus erythematosus and other connective tissue disease in Rochester Minnesota, 1950 through 1979. Mayo Clin Proc 1985; 60: 105-13.

3 Silman A J, Jannini S, Symmons D, Bacon P. An epidemiological study of scleroderma in the West Midlands. $\mathrm{Br} \mathcal{F}$ Rheumatol 1988; 27: 286-90.

4 Silman A J, Black C M. Increased incidence of spontaneous abortion infertility in women with scleroderma. Ann Rheum Dis 1988; 47: 441-4.

5 Bramwell B. Diffuse scleroderma: its frequency, its occurrence in stone masons, its treatment by fibrolysin-elevations of temperature due to fibrolysin injections. Edinburgh Medical fournal 1914; 12: 387.

6 Erasmus L D. Scleroderma in gold miners on the Witzwaterzrand with particular reference to pulmonary manifestations. Souith African Journal of Clinical Medicine, 1957 3: 209-31.

7 Rodnan G P, Benedek T G, Medsger T A, Cammaratta R J. The association of progressive systemic sclerosis (scleroderma) with coal miners pneumoconiosis and other forms of silicosis. Ann Intern Med 1967; 66: 323-34.

8 Bernstein R, Prinsloo I, Zwi S, et al. Chromosomal aberrations in occupational-associated progressive systemic sclerosis. in occupational-associated pro

9 Cowie R L. Silica-dust exposed mine workers with scleroderma (systemic sclerosis). Chest 1987; 92: 260 .

10 Haustein U F, Ziegler V. Environmentally induced systemic sclerosis-like disorders. Int $\mathcal{Y}$ Dermatol 1985; 24: 147-51.

11 Mehlhorn V J, Gerlach Ch, Ziegler V. Occupational progressive systemic sclerosis through scouring powder. Dermatosen 1990; 38: 180-4.

12 Walder B K. Solvents and scleroderma. Lancet 1965; 2 436-7.

13 Walder B K. Do solvents cause scleroderma? International Society of Tropical Dermatology 1983; 22: 157-8.

14 Czirjak L, Katalin D, Schlammadinger J, Suranyi P, Tamasi L, Szegedi G Y. Progressive systemic sclerosis occurring in patients exposed to chemicals. Int 7 Dermatol 1987; 26: 374

15 Reinl. Sclerodermic durch trichlorethylen (trans). Bulletin of Hygiene 1957; 32: 678-9.

16 Sparrow G P. A connective tissue disorder similar to vinyl chloride disease in a patient exposed to perchlorethylene. Clin Dermatol 1977; 2: 17-22.

17 Saihan E M, Burton J L, Heaton K W. A new syndrome with pigmentation, scleroderma, gynaecomastia, Raynauds and peripheral neuropathy. $\mathrm{Br} \mathcal{F}$ Dermatol 1978; 99: 437-40.

18 Lockey J E, Kelley C R, Cannon G W, et al. Progressive systemic sclerosis associated with exposure to trichloroethylene. F Occup Med 1987; 29: 493.

19 Veltman C, Lange C E, Juhe S, Stein G, Bachner V. Clinica manifestations and course of vinyl chloride disease. Ann NY Acad Sci 1975; 246: 6-17.

20 Yamakage A, Ishikawa $\mathrm{H}$, Saito $\mathrm{Y}$, et al. Occupational scleroderma-like disorders occurring in men engaged in the polymerization of epoxy resins. Dermatologica 1980; 161: 33-44.

21 Rush P J, Chaiton A. Scleroderma, renal failure and death associated with exposure to urea formaldehyde foam insulation. $\mathcal{F}$ Rheumatol 1986; 13: 475 .

22 Jones S, Silman A J. Problems ascertaining friend controls in a case control study of lung cancer [letter]. Am $\mathcal{F}$ Epidemiol 1991; 134: 673-4. 